\title{
Developing an operation, maintenance and surveillance manual for the post-closure management of tailings facilities
}

\author{
C. Crossley Department of Geological Engineering, University of British Columbia, Canada \\ B. Russell BGC Engineering, Canada \\ D. van Zyl Department of Mining Engineering, University of British Columbia, Canada \\ G. McKenna BGC Engineering, Canada
}

\begin{abstract}
Mining companies have become increasingly focused on developing environmentally responsible decommissioning and closure techniques of tailings facilities to work towards more sustainable mining practices. With the help of the Mining Association of Canada (MAC) guidelines, the development and implementation of functional and manageable Operation, Maintenance and Surveillance (OMS) manuals for operating tailings facilities have become commonplace. As more tailings facilities are decommissioned and closed, and the expectations of regulators and society continue to grow, the need for further guidance through the application of similar documentation for the management of the post-closure facility also increases. This paper highlights the importance of developing a post-closure OMS manual for the management of closed tailings facilities (and other mining landforms), by way of a post-closure OMS guidebook. It describes initial ideas in the development of post-closure OMS manuals and provides some reasoning, structure and contents for a post-closure OMS manual. It would be encouraged that tailings facility reclamation personnel utilise a universal post-closure OMS guidebook to prepare a site-specific post-closure OMS manual. This paper references a range of sources and first hand experiences by the authors.
\end{abstract}

\section{Introduction to developing a post-closure OMS manual}

Tailings storage facilities are used as a primary method for storing the waste produced from ore extraction. Tailings landforms usually occupy 25 to $75 \%$ of a mines closure landscape. These facilities are designed, operated, and closed, balancing financial, social and environmental values. The characteristics of tailings facilities are site-specific and complex, involving unique environmental settings and physical characteristics and their effective management depends on applying both managerial and technical expertise (MAC, 1998). The management of tailings storage facilities during their life cycle therefore requires specific procedures and operational controls to address the unique needs of each individual site.

When considering the guidance that has been developed for tailings management in the past, there have been some leading documents that are widely accepted and applied within Canada and abroad for mining companies. These documents include the 1998 document developed by The Mining Association of Canada (MAC), A Guide to the Management of Tailings Facilities (MAC, 1998); the 2001 MAC document, Developing an Operation, Maintenance and Surveillance (OMS) Manual for Tailings and Water Management Facilities (MAC, 2001) (further referenced here as the MAC Guidelines for developing an OMS manual for tailings operations); an Australian Government document from the Leading Practice Sustainable Development Programme for the Mining Industry, Tailings Management (DITR, 2007); and the document, Planning for Integrated Mine Closure: Toolkit, developed by the International Council on Mining and Metals in 2008 (ICMM, 2008). These documents ultimately encourage the practice of safe and environmentally responsible tailings management. Some of the approaches to safe tailings management as presented by these documents include: the development of customised, site-specific management systems; guidance for preparing site-specific OMS manuals to help define safe operation, maintenance and surveillance procedures for tailings facilities; planning for closure throughout the life cycle of a mine and not just from when operations have ceased; and that each stage in the life of a tailings storage facility, from 
conceptual design to closure and post-closure, needs to be fully considered and documented in a series of reports guiding a tailings management plan. Due to the high-risk nature of these facilities and the potential ongoing risks that follow, effective and responsible management is crucial.

The development of environmentally responsible decommissioning, closure technologies, and post-closure land use as part of the tailings facility's life cycle has received increasing attention as mining companies are progressing toward more sustainable mining practices. To fulfil this objective, mining companies have had to adapt and make additional plans for closure and any circumstances that may arise post operations (Robertson et al., 1998). In some instances, post-operational plans can be very onerous as the full extent of environmental risks associated with a tailings facility may only become apparent at or after closure. Upon closure, the care and attention towards tailings facilities is often greatly reduced as mining companies may feel their obligations have been fulfilled: the facility has been capped or covered, treatment processes are in place, the majority of the staff have left the operation and the residual risks are reduced from those during operations. Experience has shown, however, that tailings facilities after closure require ongoing monitoring and maintenance of the site as the facility can be expected to undergo a number of changes as the physical and geochemical conditions stabilise throughout the post-closure phase. If the execution and ongoing monitoring is jeopardised or neglected in any way, there is a heightened risk of negative environmental impacts, which increases the perpetual risk to public health and safety. In addition, these unforeseen issues may add a significant negative financial implication to the initial financial budgets.

Reviewing the aforementioned documents along with functional OMS manuals currently in use for operating facilities helps to establish best practices for successful operational techniques. While useful, there is a need to address the gap between the ending of the use of OMS manuals for operations and the functional and manageable OMS manuals for post-closure. At present, there is currently no document that addresses the establishment of an OMS manual for this important phase in a facility's life cycle. This paper highlights the importance of developing a post-closure OMS manual for the management of closed tailings facilities, by way of a universal post-closure OMS development guidebook, similar to that which exists for operating tailings facilities. This paper describes initial ideas in the development of post-closure OMS manuals as well as provides some reasoning, structure and contents for a post-closure OMS manual. The ideas and contents discussed in this paper have been more broadly developed in Crossley (2011). Some of the authors of this paper worked on a tailings closure project where some of the initial ideas for the OMS manual approach were identified and developed. The authors are not aware of any other tailings closure projects where such documents have been prepared and there have been no discussions with other mining companies about these concepts.

This paper references a wide range of sources and first hand experiences by the authors. The leading document utilised is the MAC Guidelines for developing an OMS manual for tailings operations which establishes an excellent framework for management controls. As a result of the MAC guidelines, the development and implementation of functional and manageable OMS manuals for operating tailings facilities have become commonplace.

\section{Closure planning and potential integration of post-closure OMS manual}

\subsection{Facility risks, life cycles and the progression of closure planning}

There are many potential risks to the natural environment, human beings and society if tailing facilities are not closed and maintained properly. While closure activities are typically set out to minimise the environmental risks, these cannot be completely negated as surface water and groundwater impacts may persist to some degree, as well as geotechnical hazards, among other things. Understanding these risks reinforces the need for a detailed, concise closure and post-closure plan. Successful closure of a tailings facility relies on minimisation, and potentially elimination, of these risks in the most economically achievable manner, thus closure and post-closure planning should begin as early as possible in the mine life cycle.

Implementation of an OMS manual allows for improved tailings management during operations and it is expected that an OMS manual, specifically designed for the closure period, would enable proper management of the facility's residual risks. Figure 1 is an illustration which depicts the progression of 
closure planning throughout the tailings facility life cycle stages, integrated with the application of operation and post-closure OMS manuals. As shown, there are three main steps in the development of a successful closure plan. The first step is conceptual closure planning which includes determining the broad closure goals for the mine site during the site selection and design phase. The iterative re-assessments and revisions to the closure plan can be placed in the second step of closure planning, as the progression towards a detailed closure plan. The third step includes the final approval of the closure plan, as well as the effective transition to closure.

TAILINGS FACILITY LIFE CYCLE STAGES

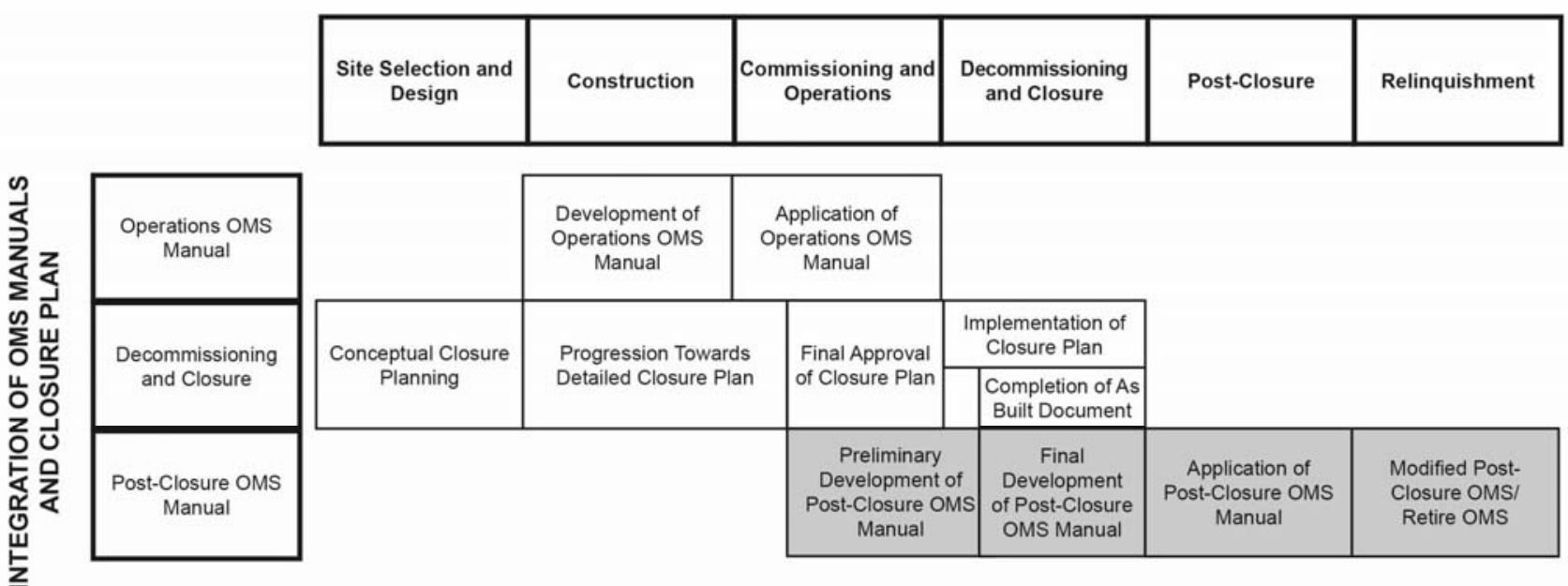

\section{Figure 1 Integration of tailings management life cycle, OMS manuals and closure plans (after} Crossley, 2011)

During the commissioning and operations stage, details for the closure plan should be fully solidified. In operations (during step two), the operations OMS manual is now utilised and the conditions, risks, advances in technology and all regulatory requirements that are relevant to the closure plan should be researched and established. Towards the end of operations, the detailed closure plan is finalised and submitted for final approval to the relevant authorities for implementation. The final plan should include detailed closure performance objectives, specific closure-related procedures, and the ongoing monitoring programme with the recommended post-closure plan and land use.

It would be very beneficial to submit a preliminary post-closure OMS manual with the submission of the closure plan. The development of the manual at this time would assist in identifying necessary instrumentation and assigning adequate resources. Once approved by the required regulatory authorities, the implementation of the closure plan and final refinement of the post-closure OMS manual can occur. It is critical during the closure-planning phase to identify and include all parties that are likely to be involved with the execution of the final closure plan (regulatory authorities and stakeholders). By doing this, the objectives of all stakeholders can be applied to the closure plan, and accordingly incorporated into the post-closure OMS manual.

\subsection{Closure goals, closure performance objectives, and closure criteria}

There will be a series of closure goals, closure performance objectives, and closure criteria that a mine must fulfil to satisfy the requirements for the agreed post-closure land use. These requirements, which are established in the closure plan, are typically determined by regulatory authorities, special agreement acts, lease conditions and stakeholder input. Table 1 provides definitions and examples of closure goals, closure performance objectives and closure criteria. 
Table 1 Closure goals, closure performance objectives and closure criteria

\begin{tabular}{lll}
\hline & Definition & Example \\
\hline Closure goals & $\begin{array}{l}\text { Broad statements that provide the vision and purpose } \\
\text { of closure. Generally established in conceptual closure } \\
\text { planning. }\end{array}$ & $\begin{array}{l}\text { Create target end land uses that } \\
\text { match and compliment the pre- } \\
\text { disturbance land conditions. }\end{array}$ \\
$\begin{array}{l}\text { Objectives that describe what closure activities are } \\
\text { performance } \\
\text { objectives }\end{array}$ & $\begin{array}{l}\text { aiming to achieve. These must be satisfied in order to } \\
\text { meet closure goals. }\end{array}$ & $\begin{array}{l}\text { Establish self-sustaining } \\
\text { vegetation which is comprised } \\
\text { of local species. }\end{array}$ \\
Closure criteria & $\begin{array}{l}\text { Criteria developed for each closure objective. These } \\
\text { criteria are measureable over a given time frame and } \\
\text { when they are met, performance objectives are met. } \\
\text { Criteria are site specific. }\end{array}$ & $\begin{array}{l}\text { Success rate of planted trees } \\
\text { measured in designated plot } \\
\text { surveys is }>85 \% .\end{array}$ \\
\hline
\end{tabular}

It is suggested that closure performance objectives and closure criteria be defined before post-closure management procedures of a tailings facility are implemented and included in the post-closure OMS manual. Objectives and criteria may evolve as more information is gathered on-site and the closure plan is further refined. As changes, unforeseen or not, occur throughout closure stages, the monitoring programme will need to be adjusted and updated. It is critical to have an organised document, such as the post-closure OMS manual, which includes all surveillance, maintenance, and monitoring parameters and can facilitate order and consistency during updates and modifications over time. The post-closure OMS manual will essentially define how to monitor and assess the closure criteria and thus meet closure performance objectives and eventually, the closure goals.

\section{The post-closure OMS plan}

\subsection{Objectives of the post-closure OMS manual}

The main objectives for developing an OMS manual for the post-closure management of a tailings facility is to:

- Define the roles and responsibilities of the key personnel involved in the management of the closed tailings facility.

- Define closure performance objectives, regulatory requirements, closure criteria, and response actions when the closure criteria are not being met.

- Outline and describe key components of the closed facility.

- Provide concise management procedures and operational controls to help meet the closed performance objectives with long term goal of lease relinquishment.

- Detail the appropriate documentation and reporting schedules.

Establishment of these objectives will help verify that the requirements of regulators and stakeholders are being adhered to, while also providing support and documentation for potential applications for future relinquishment.

\subsection{Preparing a post-closure OMS manual}

There are key elements that should be defined and understood during the preparation of an OMS manual for the post-closure management of a tailings facility. Preparation requires, but is not limited to:

- Collaborative input from stakeholders, the company and others parties so all interests can be considered during the mine closure planning and implementation process.

- A clear understanding of the closure goal(s), closure performance objectives and closure criteria. 
- Detailed descriptions and knowledge of current facility conditions, tailings properties and quantities, regulatory requirements and, potential environmental impacts and risk.

- An adequate budget and time available for the development of a functional post-closure OMS manual.

- Assemblage of a skilled OMS manual development team.

- Establishment of environmental indicators and benchmarks which will illustrate performance and demonstrate the successful completion of the closure process.

- Establishment of standards for the completion criteria that the company must achieve in order to satisfy the requirements of the regulatory authorities and stakeholders.

- Establishment of protocols and procedures for the ongoing maintenance, implementation and updating of the OMS manual.

The effort expounded toward these elements will in turn determine the effectiveness of the OMS manual and the likelihood that it will become a functional and manageable programme.

\subsection{Content of the post-closure OMS manual}

\subsubsection{Recommended structure and framework}

Each tailings facility closure project will be site-specific and therefore may require different monitoring programmes, maintenance procedures and response actions to be displayed in the post-closure OMS manual. Table 2 recommends the general structure of a site-specific post-closure OMS manual as well as suggests content that is adaptable to various site conditions. Due to space limitations, each of the following sections cannot be further elaborated. However, to provide further guidance and more detail of a post-closure OMS manual, the surveillance and alert levels sections are expanded in Section 4.

Table 2 Structure, objectives and content of a recommended post-closure OMS manual

\begin{tabular}{|c|c|c|}
\hline Heading & Objective/Scope of Including & Content to Include \\
\hline $\begin{array}{l}\text { 1.0 INTRODUCTION } \\
\text { 1.1 Objective } \\
\text { 1.2 Scope of the Manual } \\
\text { 1.3 Roles and Responsibilities } \\
\text { 1.4 Health \& Safety and } \\
\text { Permitting } \\
\text { 1.5 Reference Materials and } \\
\text { Documents }\end{array}$ & $\begin{array}{l}\text { The introduction is a clear and } \\
\text { concise way of introducing the } \\
\text { project on its individual basis. }\end{array}$ & $\begin{array}{l}\text { Provide introductory descriptions of the } \\
\text { project and site as well as a general } \\
\text { statement(s) of the closure plan. } \\
\text { Subsections should be created to include } \\
\text { information such as roles and } \\
\text { responsibilities of site personnel, site } \\
\text { permit requirements and reference } \\
\text { materials and documents that will } \\
\text { support the manual. }\end{array}$ \\
\hline $\begin{array}{l}\text { 2.0 FACILITY } \\
\text { DESCRIPTION } \\
\text { 2.1 Facility Overview } \\
\text { 2.2 Site Conditions }\end{array}$ & $\begin{array}{l}\text { It is important to provide basic } \\
\text { background information about } \\
\text { the facility. An overview of } \\
\text { the facility should set the } \\
\text { context of its surrounding, } \\
\text { while focusing on activities } \\
\text { that have led to the current } \\
\text { project. }\end{array}$ & $\begin{array}{l}\text { Include fundamentals about the facility } \\
\text { including information such as location, } \\
\text { former purpose and history as well as } \\
\text { the general site conditions that have } \\
\text { shaped the design. Reference supporting } \\
\text { documents that pertain to the details of } \\
\text { the facility. }\end{array}$ \\
\hline
\end{tabular}




\begin{tabular}{|c|c|c|}
\hline Heading & Objective/Scope of Including & Content to Include \\
\hline $\begin{array}{l}\text { 3.0 DESIGN OVERVIEW } \\
\text { 3.1 Site Characteristics } \\
\text { 3.2 Regulatory Requirements } \\
\text { 3.3 Closure Goals } \\
\text { 3.3 Closure Performance } \\
\quad \text { Objectives } \\
\text { 3.4 Facility Components }\end{array}$ & $\begin{array}{l}\text { There are many components } \\
\text { that have governed the closure } \\
\text { design of the facility and } \\
\text { therefore play a key part as to } \\
\text { how the closed facility will } \\
\text { perform post-closure. }\end{array}$ & $\begin{array}{l}\text { Include all information pertaining to the } \\
\text { closure design of the facility and directly } \\
\text { reference any supporting documents that } \\
\text { provide detailed design information. } \\
\text { Information to include is listed under the } \\
\text { design overview heading. }\end{array}$ \\
\hline $\begin{array}{l}\text { 4.0 OPERATION } \\
\text { 4.1 Objective } \\
\text { 4.2 Water Management } \\
\text { 4.3 Environmental Protection } \\
\text { 4.4 Documentation } \\
\text { 4.5 Reporting }\end{array}$ & $\begin{array}{l}\text { The transition from facility } \\
\text { operations to } \\
\text { decommissioning, closure and } \\
\text { post-closure will inherently } \\
\text { cause a shift and change in } \\
\text { operation activities, } \\
\text { procedures and objectives. }\end{array}$ & $\begin{array}{l}\text { Detail closure operations occurring on or } \\
\text { associated to the closed facility. Address } \\
\text { the purpose of operation, location of } \\
\text { operation(s) on site, basic operational } \\
\text { procedures and corresponding changes } \\
\text { of the operations based on such things as } \\
\text { seasonal influences. Example operations } \\
\text { that may be a part of closure include } \\
\text { pipe/pump systems, water treatment } \\
\text { plants, and seepage collection/ } \\
\text { underdrain system. }\end{array}$ \\
\hline
\end{tabular}

\subsection{SURVEILLANCE}

5.1 Objective

5.2 Surveillance Responsibilities

5.3 Surveillance Procedures

5.4 Surveillance Parameters

5.5 Documentation

5.6 Reporting
Surveillance of a closed tailings facility may involve varying degrees of inspection and monitoring due to the continual evolution of the site and risks associated. A detailed surveillance programme and regular review of information collected will allow for early indication of any conditions which are negatively impacting the closed facility.

\begin{tabular}{ll}
\hline 6.0 ALERT LEVELS & Alert levels are a method of \\
6.1 Definitions & identifying variances from \\
expected or desired \\
6.2 Threshold Values and & performance of the site and \\
Conditions & parameters monitored under \\
surveillance.
\end{tabular}

\subsection{ALERT LEVELS}

6.1 Definitions

6.3 Response Actions

\subsection{MAINTENANCE}

7.1 Objective

7.2 Maintenance Parameters

7.3 Maintenance Procedures

7.4 Documentation

7.5 Reporting developed to sustain any degradable features of the closed facility. Maintenance can be routine, predictive or
Discuss surveillance programs implemented on the closure surface and provide minimum requirements and or objectives the programme is to achieve. A surveillance programme typically encompasses both visual inspections and instrumentation. Specific procedures and parameters for conducting these visual inspections and instrumentation readings should be defined.
Identify thresholds of either visual indicators or instrumentation measurements that determine when the closed facility is performing unacceptably. Potential failure modes should be identified, along with the appropriate response actions for the various levels of threshold exceedance.

Detail the maintenance programme for A maintenance plan should be event-driven and is necessary to prevent degradation of the facility to unacceptable levels. the closed facility. Identify and describe the routine, predictive and event-driven maintenance for all civil, mechanical, electrical and instrumentation components of a facility (MAC, 2001). Example components and parameters that may require maintenance include: site access year round, pump wear and erosion. 


\begin{tabular}{|c|c|c|}
\hline Heading & Objective/Scope of Including & Content to Include \\
\hline $\begin{array}{l}\text { 8.0 EMERGENCY } \\
\text { PLANNING AND } \\
\text { RESPONSE } \\
\text { 8.1 Objective } \\
\text { 8.2 Warning Signs and } \\
\quad \text { Emergency Situations } \\
\text { 8.3 Contents of Emergency } \\
\quad \text { Preparedness and Response } \\
\quad \text { Plans }\end{array}$ & $\begin{array}{l}\text { Despite best efforts to } \\
\text { establish safe and responsible } \\
\text { management procedures, the } \\
\text { high risk nature and ongoing } \\
\text { risks that are associated with } \\
\text { closed tailings facilities } \\
\text { require emergency } \\
\text { preparedness and response } \\
\text { (EPR) plans for unforeseen } \\
\text { events and conditions. }\end{array}$ & $\begin{array}{l}\text { Outline the EPR plans to identify the } \\
\text { potentials for accidents, to respond in } \\
\text { emergency situations, and to prevent and } \\
\text { mitigate the environmental and safety } \\
\text { impacts, both on and off-site, associative } \\
\text { with emergency situations (MAC, 2001). }\end{array}$ \\
\hline
\end{tabular}

\section{$4 \quad$ Suggested expanded content for surveillance and alert levels}

\subsection{Surveillance}

A surveillance programme may encompass a range of multi-disciplinary aspects to complete the inspections, readings, and assessments of all parameters with a closed tailings facility. It is important that all personnel involved with the post-closure surveillance programme be routinely aware of their responsibilities in order to maintain consistent awareness of the facility's performance. It is also crucial that personnel are well trained in the response actions and reporting required when deviations from expected behaviour occur.

\subsubsection{Surveillance procedures}

Surveillance consists of a series of routine and event-driven procedures that must be clearly defined and followed to monitor the surveillance parameters. Visual inspections and instrument reading, which are integral to, and done as part of routine surveillance, may also be essential within the context of event-driven surveillance (MAC, 2001). Table 3, adapted from a table in MAC (2001), highlights the typical surveillance procedures that may be encountered on a closed tailing facility landscape.

\section{Table 3 Example surveillance procedures}

\section{Visual Monitoring and Inspection}

Weekly and monthly routine inspections by trained personnel.

Periodic inspections by engineering and/or specialist personnel.

\section{Instrumentation Measurement}

\begin{tabular}{lll}
\hline Surveying $\quad$ Instrument reading & Material testing & Sampling \\
\hline Data Collation and Analysis & & \\
\hline
\end{tabular}

Routine visual inspection observations and field data as collected to determine whether closure surface performance is meeting closure criteria and performance objectives.

Comparison with thresholds.

Follow-up inspections of collated observation logs and data to determine trends as related to closure criteria.

\section{Follow-up Inspections and Review}

Of all collected observation logs from visual inspections and instrumentation readings.

Of complete closure facility performance.

Of continuing validity of closure design, performance objectives and closure criteria.

\section{Documentation}

\section{Reporting}




\subsubsection{Surveillance parameters}

Surveillance parameters identify the specific elements of the facility that may provide indication as to whether the landscape and components are performing as expected. These parameters can be identified through either visual inspection or monitoring of instrumentation. Table 4 highlights typical surveillance parameters, their monitoring approach and the corresponding indicators or instrumentation.

Table 4 Example surveillance parameters and methods

\begin{tabular}{|c|c|c|c|}
\hline $\begin{array}{l}\text { Surveillance } \\
\text { Parameter }\end{array}$ & $\begin{array}{l}\text { Monitoring } \\
\text { Approach }\end{array}$ & Visual Indicators & $\begin{array}{l}\text { Instrumentation and } \\
\text { Survey Methods }\end{array}$ \\
\hline $\begin{array}{l}\text { Surface } \\
\text { deformations }\end{array}$ & $\begin{array}{l}\text { Visual and } \\
\text { instrumentation }\end{array}$ & Cracking, bulging, sinkholes, etc. & $\begin{array}{l}\text { Survey monuments, slope } \\
\text { inclinometers }\end{array}$ \\
\hline Soils & $\begin{array}{l}\text { Visual and } \\
\text { instrumentation }\end{array}$ & $\begin{array}{l}\text { Erosion/erosion gullies, and } \\
\text { salinisation }\end{array}$ & Soil moisture sensors \\
\hline Seepage & Visual & Quantity and appearance & N/A \\
\hline Surface water & $\begin{array}{l}\text { Visual and } \\
\text { instrumentation }\end{array}$ & $\begin{array}{l}\text { Locations, levels, quality, balance } \\
\text { and appearance }\end{array}$ & $\begin{array}{l}\text { Probes, sampling and lab } \\
\text { testing, staff gauges, weirs, } \\
\text { pipeline totalisers, etc. }\end{array}$ \\
\hline Groundwater & Instrumentation & N/A & Piezometers and wells \\
\hline Vegetation & Visual and surveys & Die-back, stressed vegetation & $\begin{array}{l}\text { Discrete vegetation surveys } \\
\text { and remote sensing }\end{array}$ \\
\hline Wildlife & Visual and surveys & $\begin{array}{l}\text { Sightings of various species, } \\
\text { number, use (nesting, habitation) of } \\
\text { particular wildlife features }\end{array}$ & Discrete wildlife surveys \\
\hline
\end{tabular}

\subsection{Alert levels and response}

Once a visual monitoring and instrumentation monitoring programme has been developed for a surveillance programme, it is suggested to affirm the required closure criteria as well as identify the thresholds that may indicate when the closure surface is performing unacceptably. One way of establishing the different degrees of the closed facility's performance is by creating alert levels in the form of green, yellow, orange and red.

\subsubsection{Definitions, threshold values and conditions, and response actions}

Each colour will represent varying degrees to which an unacceptable condition(s) has developed, and will require various levels of response actions. These alert levels essentially define the level of severity and should be defined with consideration for such things as potential risk to humans, to the environment and to wildlife. Once alert levels are defined, the threshold values or conditions for different surveillance parameters and instrumentation can be developed for each level of alert. The reasons as to why specific threshold values have been selected should also be provided so that monitoring personnel can understand the importance and potential impacts of exceedances. For each level of alert, a response action will be required. These response actions can be defined in a similar format to the alert level definitions and are generally specified in relation to the severity of the condition. Table 5 depicts example alert level definitions, example threshold values for observations of seepage as well as corresponding response actions. Seepage is just one visual indicator that may be anticipated at an assumed closed tailings facility. Threshold values for other visual indicators, as well as natural events such as heavy rainfall and earthquakes, and site instrumentation should also utilise a similar format. 
Table 5 Example alert level definitions, thresholds for observations of seepage and response actions for a closed facility

\begin{tabular}{|c|c|c|}
\hline Example Definitions & $\begin{array}{l}\text { Example Seepage Threshold } \\
\text { Values }\end{array}$ & Example Response Actions \\
\hline \multicolumn{3}{|l|}{ GREEN } \\
\hline $\begin{array}{l}\text { The closed facility is } \\
\text { performing acceptably } \\
\text { and surveillance data and } \\
\text { analysis suggests there is } \\
\text { low potential for the } \\
\text { development of } \\
\text { unfavourable conditions. }\end{array}$ & $\begin{array}{l}\text { - No identification of new } \\
\text { locations or no increase in } \\
\text { already identified areas of } \\
\text { concern. }\end{array}$ & $\begin{array}{l}\text { - Surveillance of the closed tailings facility } \\
\text { would continue according to current } \\
\text { monitoring schedules. }\end{array}$ \\
\hline \multicolumn{3}{|l|}{ YELLOW } \\
\hline $\begin{array}{l}\text { The closed facility is } \\
\text { performing acceptably } \\
\text { but a higher level of alert } \\
\text { is advised when field } \\
\text { inspections and/or } \\
\text { instrumentation data } \\
\text { indicate that there is a } \\
\text { potential for the } \\
\text { development of } \\
\text { unfavourable conditions. }\end{array}$ & $\begin{array}{l}\text { - New location identified. } \\
\text { - Flowrates are observed to } \\
\text { increase by approximately } \\
1.5 \text { times. } \\
\text { - Visual quality has } \\
\text { noticeably changed, with } \\
\text { increased amount of } \\
\text { suspended particles or } \\
\text { murkiness. }\end{array}$ & $\begin{array}{l}\text { Key monitoring personnel should inform } \\
\text { their supervisor, and/or any specialist } \\
\text { engineer/scientist who assists in assessing } \\
\text { the site performance, of the observations } \\
\text { and data. } \\
\text { - The potential actions may include an } \\
\text { increase of instrumentation and visual } \\
\text { monitoring, depending on condition, data, } \\
\text { or observations which yield a yellow alert. } \\
\text { - A complete visual inspection and collection } \\
\text { of instrumentation measurements should be } \\
\text { conducted within area in which the yellow } \\
\text { alert condition has been reached. }\end{array}$ \\
\hline
\end{tabular}

\section{ORANGE}

The field inspections and/or instrumentation data indicate that performance of the closed facility has degraded below an acceptable level; however, immediate remedial measures are not required.
- Observations at more than one new location.

- Flowrates are observed to increase by approximately 3 times.

- Visual quality has markedly deteriorated, with moderate brown or red discolouration.
- In addition to the yellow alert responses, the mining company and any specialist engineer/scientist should develop a design and implementation plan for remedial measures. The implementation plan shall include consideration for logistics, access, material availability and schedule confirming that the remedial measures can be implemented within the required time if the situation develops into a red condition.

\section{RED}

The closed facility's performance has degraded below the acceptable level and remedial measures emergency response measures are required immediately.
- Observations at more than four new locations.

- Flowrates are observed to increase by approximately 5 times.

- Visual quality has markedly deteriorated, with definite brown.
- The mining company would implement the remedial measures immediately if such design has already been completed. If not, the mining company and any specialist engineer/scientist should carry out a detailed assessment and design of remedial measures as outlined for the orange condition.

- Red discolouration. 


\section{Conclusions}

To help reach successful closure it is good practice that throughout operations decommissioning, closure, and post-closure OMS manuals be utilised to provide standardised procedures and operating guidelines for the facility. A post-closure OMS manual will bridge the gap between the closure guidelines established in the closure plan and the implementation of programmes and resources required on-site to assist in the environmentally safe and responsible management of a closed facility. The benefits from utilising a post-closure OMS manual will help to achieve mining companies' objective of more sustainable mining practices.

\section{References}

Crossley, C. (2011) Developing an Operation, Maintenance and Surveillance Manual for the Post-closure Management of a Closed Tailings Facility, created for BASc Thesis requirement, Department of Geological Engineering, University of British Columbia (UBC), Vancouver, $82 \mathrm{p}$.

DITR (2007) Department of Industry Tourism and Resources. Tailings Management, Leading Practice Sustainable Development for the Mining Industry, Australian Government, 79 p., viewed 4 May 2011, www.ret.gov.au/resources/documents/LPSDP/LPSDP-TailingsHandbook.pdf.

ICMM (2008) International Council on Mining and Metals. Planning for Integrated Mine Closure: Toolkit, 86 p., viewed 30 April 2011, www.icmm.com/document/310/.

MAC (1998) Mining Association of Canada. A Guide to the Management of Tailings Facilities, 54 p., viewed May 3, 2011, www.mining.ca/www/media_lib/TSM_Documents/TSM_Publications/tailingsguide.pdf.

MAC (2001) Mining Association of Canada. Developing an Operation Maintenance Surveillance Manual for Tailings and Water Management Facilities, 49 p., viewed 3 May 2011, www.mining.ca/www/media_lib/MAC_Documents/omsguideeng.pdf.

Robertson, A., Shaw, S. and Devenny, D. (1998) Post Mining Sustainable Use Plans vs. Closure Plans. In Mine Reclamation and Remediation, Proceedings Twenty-second Annual British Columbia Mine Reclamation Symposium, September 14-17, Penticton, B.C., pp. 95-110. 